\title{
Life after incubation: The impact of entrepreneurial universities on the long-term performance of their spin-offs
}

\begin{abstract}
The concept of the entrepreneurial university advocates the importance of the economic and societal impacts of universities through, among other things, the creation of spin-offs. With regard to supporting the early growth of spin-offs, literature has consistently emphasized the role of spatial and social proximity to universities in providing access to resources and facilitating technology transfer. However, little is known about the relationship between universities and their spin-offs, especially after incubation programs have been completed. Using a sample of 100 spin-offs from two universities in Europe, we develop several hypotheses predicting the motivation to maintain proximity to universities and the impact on performance. The findings suggest that factors such as research orientation, entrepreneurial orientation and market hostility encourage spin-offs to maintain proximity to universities. However, spin-offs experience diminishing returns in performance as commercial activities are reduced due to them over-pursuing proximity. More specifically, spin-offs with a high entrepreneurial orientation perform strongly if they are able to balance their level of proximity to universities. Our study contributes to the current discussion on the role of the university in supporting entrepreneurial activities and sparks a new debate on how to support the long-term growth of spin-offs, including differentiation in support according to entrepreneurial orientation, as well as flexibility in support.
\end{abstract}

Keywords: Incubator, Proximity, University, Spin-offs, Performance. 


\section{Introduction}

Over the past two decades governments from around the world have become ever more directive in their funding of the higher education sector and put pressure for transforming research into economic growth, innovation and employability (Etzkowitz et al., 2000). This pressure has transformed universities and made them become more entrepreneurial in their nature (Guerrero and Urbano, 2012). Many have developed activities, such as research collaborations with industries, creative ways of commercialising patents, and entrepreneurial training for students and industries to achieve their entrepreneurial aspiration (Somsuk and Laosirihongthong, 2014; Urbano et al., 2016; Taheri and van Geenhuizen, 2016). Giving greater attention to the linkage between their inventions and the real-life societal and economic impacts, universities are moving away from their traditional roles of research and teaching to a more advanced and complex role of promoting academic entrepreneurship (Lerner, 2004; Svensson et al., 2012).

Studies about the entrepreneurial university have traditionally focused on the transformation of their organisational structures to enable and enhance the creation of university spin-offs. While attention has been poured on incubators and incubation processes as an instrument of supporting spin-offs (e.g. Mian, 1994, Mian et al., 1996; McAdam et al., 2006; Soetanto and Jack, 2016; van Weele et al., 2017), policies have shown a significant bias toward the creation process of these entrepreneurial firms. Studies have largely concentrated on the types of support that are critical to overcoming obstacles during the early stages of new venture development (e.g., Benneworth and Charles, 2005; Ndonzuau et al., 2002; Soetanto and Jack, 2016; Treibich et al., 2013) and neglect the relevance of the university's role in the context of mature and independent spin-offs. Typical incubation support, such as access to low-rent accommodation and services, research facilities, business advice and networks and networking, may overlook the unforeseen challenges spin-offs face after leaving the incubator and finishing their participation in coaching programs. The fact that little is known regarding the long-term impact of universities on their spin-offs' performance, justifies the needs for studies focusing on post-incubation performance of university spin-offs in the context of the entrepreneurial university.

This study aims to investigate the nature of the relationships between universities and their spin-offs, especially after they have left incubators and finalized coaching programs. Using 100 university spin-offs that have 'graduated' from university-based incubators in Norway and the Netherlands during the period of 2007-2011, this study addresses the following questions: In which ways does the role of entrepreneurial universities extend beyond the early years of their 
spin-offs' development? To what extent does maintaining spatial and social proximity to the university influence the performance of university spin-offs? What policies need to be designed in order to support the post-incubation performance of university spin-offs? In answering those questions, the study hypothetically predicts the effect of the characteristics of spin-offs and the market in influencing and moderating the relationship between proximity to university and performance.

The study makes several key contributions to the literature and policy practices on the entrepreneurial university. First, it offers answers on how the entrepreneurial university can strategically sustain its impact on economic growth and innovation. In this case, the study reinvigorates new types of policy support for spin-offs beyond the incubation period. Designing post-incubation policy is becoming critical for university spin-offs as they may not yet meet the initial expectation despite being a popular means for fulfilling the 'third mission' of entrepreneurial university (Tavoletti, 2013) beyond the first two: to perform education and research. Studies found that most university spin-offs do not grow, grow slowly (Mustar et al., 2008) or do not perform as well as other technological start-ups (Wennberg et al., 2011). Our study should therefore be of substantial interest to all of the stakeholders of any entrepreneurial university to support their entrepreneurship activities. Second, our research sheds light on how spin-offs respond to environmental change as a result of leaving the incubator and/or completing participation in support programs. In this respect, we offer a response to the calls to generate novel insights for further research and theoretical underpinning on university spinoffs and their long-term performance (Clarysse et al., 2011), which has received little response so far (Rodríguez-Gulías et al., 2017). Third, the study provides more understanding on factors that encourage university spin-offs to stay in the region after leaving the incubators, and maintain close interaction with the university. This is important especially to sustain universities' contribution to the regional economy and innovation capacity. Taken together, our contributions highlight important considerations to prepare spin-offs to face life after incubation and open a new discussion on the role of the entrepreneurial university particularly on the benefits of incubation programme (Rothaermel and Thursby, 2005; Clarysse et al., 2011; Lasrado et al., 2016).

\section{Theoretical development}

\subsection{Entrepreneurial University: Making an impact through the creation of university spin-offs}


Universities are organisations that play a key role within society to perform education and research. In recent decades, many universities have taken action to develop a third mission by fostering technology transfer activities (Etzkowitz et al., 2000; Svensson et al., 2012; Perkmann et al., 2013). Entrepreneurial university is the concept that has been developed to ensure that the knowledge generated contributes to regional economic development (Bygrave and Minniti, 2000; Benneworth and Charles, 2006; Bathelt et al., 2010; Fayolle and Redford, 2015). For the purpose of our study, it is necessary to identify the salient features of the concept of the entrepreneurial university as one which is able to survive and adapt in highly complex and uncertain conditions by performing entrepreneurial activities and contributing to regional and national economic development (Clark, 2001). While most studies on entrepreneurial universities focus on their performing various entrepreneurial activities through education and research, sustaining the contributions to (regional) growth can be effectively achieved by exploiting technological knowledge that originates within a university through the creation of university spin-offs (Etzkowitz et al., 2000; Guerrero and Urbano, 2014). There are several reasons for the growing importance of university spin-offs in the context of the entrepreneurial university. First, spin-offs offer rapid evolution of scientific knowledge into marketable products or services (Shane, 2004). Secondly, they are increasingly important in their role within business and innovation ecosystems. Through their flexibility and openness, they may partly act as knowledge connectors and even as intermediaries in the local/regional Triple/Quadruple Helix networks (Pisano, 2006; van Geenhuizen et al., 2016; Hayter, 2016). Thirdly, many policies have been created following legislative changes that have specifically targeted the creation of university spin-offs.

Similar to other entrepreneurial firms, university spin-offs require assistance to overcome initial resource constraints (Barney and Clark, 2007; Katila et al., 2008), like gaining access to relatively cheap accommodation, research facilities, meeting rooms, etc. (Bergek and Normann, 2008), potential investors (Gulati and Higgis, 2003; Lockett and Wright, 2005), alliance partners (Pollock and Gulati, 2007; Schwartz and Hornych, 2010) and market knowledge and customers (Elfring and Hulsink, 2003). To respond to those needs, universitybased incubators have been developed to provide (access to) physical capital, financial capital, knowledge (technical, management, market), social capital and legitimacy (Etzkowitz et al., 2000; Schulte, 2004; van Weele et al, 2017). However, recent empirical studies (e.g. Schwartz, 2011; Lasrado et al., 2016) have started to indicate that university spin-offs may not be well prepared for long-term growth in facing changes due to the transformation from working in a 
protected environment such as incubators to a new and unsupported environment after incubation.

\subsection{Life after incubation: environmental change and the problems after graduation}

Studying firms from five incubators in Germany, Schwartz (2011) finds that moving out of the incubator facility causes an immediate negative effect on performance that lasts up to three years. A study in the US finds that incubated firms outperform their peers in terms of employment and sales growth during incubation, but performance declines significantly soon after leaving the incubator (Amezcua, 2010). Moreover, Lasrado et al. (2016) show that incubated firms may not benefit significantly from their incubator relationships and may even be more vulnerable to failure after ending these relationships. While these empirical studies indicate a potential drawback and risky path for spin-offs after graduating from incubators, organisational studies literature (e.g. Hannan and Freeman, 1984; Levitt and March, 1988; Feldman and Pentland, 2003) suggests that routines and competencies developed as a result of incubation may be misaligned with the real competitive environment outside. In addition, in transforming themselves from incubated firms to independent firms, spin-offs are subject to strong inertial forces and seldom succeed in making radical changes in the face of environmental threats (Hannan and Freeman, 1984; Chattopadhyay et al., 2001). The lock-in effect created by formal institutional links and social relationships among incubated firms may expose their weaknesses in terms of organisational responsiveness and adapting to the new environment outside of incubators (Narula, 2002; Sydow et al., 2009). Even after receiving incubation support for three to four years, spin-offs may not yet have developed their full potential when market legitimacy has only been partially gained (Rasmussen et al., 2011; Tavoletti, 2013).

In order to understand how the change from such a supported environment to an unprotected one may affect spin-offs, we adopt the approach of organisational change. From reviewing the literature, two main perspectives emerge in relation to responses to change. On the one hand, theories lean towards a more voluntarist orientation of organisational change, arguing that organisations are continuously constructed, sustained, and transform in response to environmental change (Levinthal and March, 1981; Todnem, 2005). In this case, change is a part of the element that continuously forms the organisation over time. In this perspective, the organisation can be defined as a function of the match between the organisational structure, processes, and the external environment (Hrebiniak and Joyce, 1985). The changing 
environment after leaving the incubators is a natural process where spin-offs use their flexibility and capabilities to adapt. Spin-offs may move away from a university's premises or stay in proximity and continuously maintain relationships with it.

On the other hand, organisational theories promote the so-called concept of organisational inertia, arguing that organisations are limited in their ability to adapt their strategies to their external environment and therefore tend to persist in using their past strategies despite environmental changes (Liao et al., 2003; Hannan and Freeman, 1984). Population ecology theory asserts that organisations face both internal and external resistance, and therefore their ability to respond to external changes is restricted (Hannan and Freeman, 1984; Amburgey and Rao, 1996). In addition, cognitive theories state that organisational strategists have a limited capacity to process information (Kiesler and Sproull, 1982; March and Simon, 1958), and therefore operate in organisational contexts often characterized by pressure to maintain current strategies (Shepherd et al., 2016). The structural inertia created by routines and the environment during incubation force spin-offs to maintain proximity to universities after having left their incubator. University spin-offs are often limited in their resources and their ability to adopt new approaches and mechanisms; leaving the incubator therefore leads to a significant consequence in the form of diminishing incubation support. This implies that the spin-offs need to develop a new organizational culture and social capital in a new location, which may entail significant resources and time. Moreover, they may not yet have developed established relationships, trust, and solid ties with customers and suppliers and may still lack an adequate supply of financial capital for further growth (Mustar et al., 2006; Stuart and Sorenson, 2007). Failure to adapt quickly or find additional support may risk their future growth.

Likewise, the debate in the practical spectrum of designing new incubation support is unclear on how university spin-offs react to environmental change as a result of leaving the incubators (Escribano et al., 2009; Muzzi and Albertini, 2015; Sapienza et al., 2006; Teece, 2009; van Weele et al., 2017). The common phenomenon observed is the tendency to maintain proximity to universities. This is in line with literature on the entrepreneurial university where the interaction between university and industry creates a positive impact on regional growth (Rothaermel and Thursby, 2005; Fini et al., 2011; Svensson et al., 2012). Spin-offs may benefit from access to the university's research activities, which arguably makes them more innovative and allows them to respond faster in terms of research commercialisation, with direct and indirect employment growth as a result. Based on the above discussion, we hypothetically predict that university spin-offs maintain proximity even after graduating from incubators in order to maintain access to the university's resources. 
This study follows extant literature in classifying proximity as spatial and social. While spatial proximity is defined in terms of the physical distance between spin-offs and their parent university, social proximity refers to socially embedded relations and the closeness of individuals, leading to trust based on friendship, kinship, and long-term relations (Boschma, 2005). The following section presents the hypotheses in this study.

\subsection{Reasons for maintaining proximity to universities}

According to Pirnay and Surlemont (2003), university spin-offs are usually initiated by individuals with a scientific background, including those with substantial research experience, such as professors, assistants, researchers, doctoral students (Clarysse et al., 2005; Mustar, 1997), or students with less of a research background (Laukkanen, 2000). In university spinoffs founded by students, the business often aims to exploit opportunities that are rarely grounded in extensive research activities, and tend to concentrate on sectors with low entry barriers, such as IT and services (Pirnay et al., 2003; Mustar et al., 2006; Guerrero and Urbano, 2012). In contrast, research-oriented spin-offs started by university research staff often aim to penetrate a niche market with a new design or technology. Compared to student entrepreneurs, research-oriented entrepreneurs face more obstacles and higher risks due to the nature of the innovation and the uncertainty of market acceptance (Pirnay et al., 2003). Research-oriented spin-offs may also develop stronger attachment to universities due to entrepreneurs' academic positions, careers, and social ties (Johansson et al., 2005). As a result, this type of spin-off relies heavily on support from the university and may therefore suffer from significant problems when moving out from the incubator compared to spin-offs founded by students.

For this reason, we posit that research-oriented spin-offs may attempt to maintain long-term spatial and social proximity to their university after leaving the incubators. In more detail, this argument is based on the following: the technological content of their products or services may force research-oriented spin-offs to maintain continuous access to the university's research facilities (Ndonzuau et al., 2002; Rothaermel and Thursby, 2005; Fini et al., 2011), in particular, access to front-line research and collaborative networks with the university without excluding the fact that some spin-offs also start to internationalize, i.e., build additional knowledge relations abroad and even act as born global firms (Taheri and van Geenhuizen, 2011). They may also need to be located close to the university to sustain the social ties they have built with other researchers there, enabling them to exchange tacit knowledge in overcoming technical obstacles and acquiring new technology (Ndonzuau et al., 2002; Johansson et al., 2005). Trust-based relationships facilitate the exchange of tacit knowledge, 
which by its nature is more difficult to communicate, and as a prerequisite of interactive learning makes innovation easier (Boschma, 2005; Maskell and Malmberg, 1999). Another reason is that founders' full/part time work activity at the university (or university hospital) while exploring the commercial opportunities at the incubator, means it is more convenient to be at a shorter distance (Steffensen et al., 2000). Part-time arrangements provide the founders with the possibility of additional income and simplify a subsequent return to the university in case of failure. Based on the above arguments, we state the following hypothesis:

H1. University spin-offs with research-oriented founders are more likely to maintain spatial and social proximity to entrepreneurial universities after leaving the incubator facilities.

Another important reason to remain close to the university is the nature of the entrepreneurs' risk-taking behaviour and the ability to recognise opportunity. We argue that spin-off characteristics, such as entrepreneurial orientation, may endorse the long-term development of proximity to the university (Wright et al., 2007). Entrepreneurial orientation refers to the processes, structures, and behaviours characterized by innovativeness, proactiveness, risk taking, and competitive aggressiveness (Covin and Slevin, 1989; Lumpkin and Dess, 1996; Miller and Friesen, 1983). Highly entrepreneurial-oriented spin-offs are likely to appreciate the emerging opportunities that universities develop in their laboratories or research facilities (Steffensen et al., 2000; Mustar et al., 2006). Interaction with scientists and students especially at the entrepreneurial university creates highly specialized and new ideas with commercialisation potential. As a result, proximity to the entrepreneurial university helps spinoffs with a high entrepreneurial orientation to continuously identify new opportunities, maintain their leading position over competitors and foster long-term growth. In addition to local networks, they also develop early networks in knowledge exchange abroad, partly 'fuelled' by international research contacts at the university (Walter et al., 2006; Wright et al., 2007). We thus argue that spin-offs with high entrepreneurial orientation are more likely to benefit from universities after incubation. Maintaining continuous access to university resources and the presence of locally bounded social capital at the university help university spin-offs to overcome challenges and gradually adjust to the new environment (Johansson et al., 2005; Rothaermel and Thursby, 2005). In addition, the entrepreneurial university ecosystem, including access to specialized markets and knowledge, may provide potential opportunities (Johansson et al., 2005; Bathelt et al., 2010). The following hypothesis outlines our argument: 
H2. University spin-offs with high entrepreneurial orientation are more likely to maintain spatial and social proximity to entrepreneurial universities after leaving the incubator facilities.

The next factor that possibly motivates spin-offs to maintain long-term relationships with universities is the threat from the market and competition. In commercialising an innovative and technology-based product, spin-offs may face challenges from fierce competition, unpredictable market acceptance, radical industry changes, and uncertainty with regard to technology development and patenting (Brouthers et al., 1996; Slater et al., 2014). These spinoffs must therefore dedicate resources to manage such an unfavourable environment and to ensure achieving their organizational goals (Zahra, 1993). For small firms, such as university spin-offs, a strategic option is to generate contingent strategies, such as collaboration and networking to overcome market hostility (Walter et al., 2006). Thus, in the event of leaving the incubator, responding to strong pressure and a hostile market, the spin-off prefers to be located close to the university or maintain strong ties with the university's contacts (Steffensen et al., 2000; Johansson et al., 2005; Egeln et al., 2004). While the amount and level of support from incubators diminishes, access to academics at the university reduces the transaction cost of accessing research and innovation while at the same time using the resource to overcome market hostility. In the case of entrepreneurial university, the involvement of external stakeholders such as venture capitalists, consultants, and government intermediary bodies may help spin-offs to overcome obstacles or exploit new opportunities. Empirical evidence on hightechnology clusters - for example, Route 128 (Boston-US) and the Cambridge cluster (UK) shows similar processes on a larger scale, whereby high technology firms are likely to cluster near knowledge infrastructures (Keeble and Wilkinson, 2000). Such concentrated clusters indicate that firms in volatile and hostile markets benefit from spatial proximity and long-term relationships with universities (Keeble and Wilkinson, 2000; Egeln et al., 2004). This argument is proposed in the next hypothesis:

H3. University spin-offs facing hostile markets are more likely to maintain spatial and social proximity to entrepreneurial universities after leaving the incubator facilities.

\subsection{Limits in the proximity-performance relationship}

As previously indicated, we argue that certain segments of spin-offs tend to maintain spatial and social proximity to universities after leaving the incubator and participation in support 
programs. Literature is very explicit in arguing that spatial and social proximity facilitate the exchange of tacit knowledge, which is by its nature much more difficult to communicate and trade through the market (Maskell and Malmberg, 1999; Keeble and Wilkinson, 2000). Spatial proximity entails lower transport and transmission costs and provides greater opportunities for two agents to meet, eventually leading to serendipity (Morgan, 2004). The exchange of tacit knowledge may increase the innovation and productive capacity of spin-offs and thereby enhance their growth potential. Previous studies (e.g., Argote and Miron-Spektor, 2011; Sears and Hoetker, 2014) argue that efficient learning and knowledge generation can be endorsed by shared knowledge commonality between spin-offs and their parent university. In this vein, scholars such as Nelson (1993), Cooke (2001), and Lundvall et al. (2011) argue that social proximity encourages social and open attitudes towards innovation rather than a calculative and narrow market orientation. As a result, entrepreneurs may maintain relationships with their former colleagues and remain involved in a range of entrepreneurial activities, such as common research projects, subcontracting university research, participating in new university courses, and daily interactions while using university laboratories. Overall, proximity to the entrepreneurial university will enhance the ability of spin-offs to maintain their innovation activities by keeping abreast of new information and technology progress, and speeding up problem-solving processes.

However, not specifically understood is whether this positive relationship exists infinitely. Indeed, there may be a saturation point above which the over-pursuit of spatial and social proximity to universities may have adverse effects on the performance of spin-offs. Taking into account general notions on increasing/decreasing returns and path dependency (Arthur, 1994; Grabher, 1993), we could expect increasing returns when proximity is constructed and elaborated, followed by diminishing returns accompanied by lock-in effects (Maurer and Ebers, 2006). These negative influences tend to impede the ability of spin-offs to capture opportunities as it takes increasingly more time and effort to build new capabilities and adjust to new routines. For university spin-offs, leaving the incubator implies a shift from a protected environment towards a market-controlled one. The contradictions of the two antagonistic environments may create stress and confusion for entrepreneurial firms operating in the new environment. The outcome of stress and confusion may be the inability to capitalize on new business opportunities efficiently (Dyer, 1994), i.e., when entrepreneurial spin-offs develop very close proximity with the university and focus too much of their attention on engaging in high-risk and innovative projects in the new situation. Accordingly, they may ignore or underestimate the constraining functions of the two opposing systems (Bruton and Ahlstrom, 
2003). Receiving abundant support due to proximity to the university may lock spin-offs in their own context and lead them to overlook growth opportunities in the market. Under these circumstances, being located close to the university and strongly interacting in university networks may inhibit spin-offs from growing and reaching their full potential as independent firms. Therefore, we propose the following hypothesis:

H4. Spatial and social proximity have an inverted U-shaped relationship with spin-off performance.

\subsection{The complexity in the proximity-performance relationship: moderation effect}

Although proximity has a positive effect on the performance of spin-offs, there is a potential risk for them with a high emphasis on research activities. Focusing on exploration can provide numerous potential opportunities through (participation in) the university's research activities. As a result, these spin-offs may overlook obstacles and problems in their existing processes that potentially deviate from their initial strategy. If this proximity is too close or strong, the impact results in declining performance. Experimenting with new and innovative ideas may distract university spin-offs from executing their current business (McGrath, 1999). In contrast, research-oriented spin-offs with very low proximity to the university may struggle to access research and facilities for exploration activities (Narula, 2002; Fini et al., 2011). This may suggest that the effect of proximity on performance could vary according to the contextual conditions. Consequently, we argue that a research-oriented spin-off that balances the level of proximity to the university is able to fully engage with both the academic and the business world, which is more likely to lead to strong performance. Moreover, we also argue that research-oriented spin-offs are more able to translate such advantages into performance compared to those focusing less on research activities (Pirnay et al., 2003). The common technical language and knowledge base will foster knowledge exchange activities between the university and the university spin-off. With an intermediate level of proximity, researchoriented spin-offs enjoy a greater degree of novelty as a result of the university's research activities, without the risk of getting locked-in to the university's network. This ability to balance the level of proximity provides opportunities for research-oriented spin-offs to actively explore new and varied experiences with the university and exploit these for commercial returns. Thus, we propose: 
H5. Research-oriented spin-offs moderate the inverted U-shaped relation between proximity and performance such that research-oriented spin-offs experience stronger performance as a result of balancing proximity to the university compared to spin-offs that focus less on research.

Moreover, we also expect entrepreneurial orientation to moderate the relationship between proximity and performance. Compared to spin-offs with a low entrepreneurial orientation, those with a high entrepreneurial orientation may produce strong performance as a result of balancing proximity to the university. In this case, we posit that high entrepreneurial orientation strengthens the positive effect of proximity when the level of proximity is relatively low or moderate. As norms and trust have not been fully established when proximity is low to moderate, the exchange parties may have ambiguous or incomplete understanding of each other's information needs and resource obligations. High entrepreneurial orientation will reduce ambiguity and enhance the commercialisation process through a more innovative and risk-taking approach, thus increasing the opportunity for commercial activities through observing the research activities of the university (Grinstein, 2008; Miller and Shamsie, 1996). However, we further argue that when proximity is too close, high entrepreneurial orientation may not lead to a positive effect on performance (Miller and Friesen, 1983). Spin-offs with high entrepreneurial orientation may miss capturing opportunities outside the university's domain as they may commit too many resources to developing close proximity to the university. Moreover, compared to spin-offs with low entrepreneurial orientation, they will not be quick and effective enough to respond to new market opportunities or to external threats as their strong ties with the university constrains their decision-making process. For this reason, we propose the following hypothesis:

H6. Entrepreneurial orientation moderates the inverted U-shaped relation between proximity and performance such that spin-offs with high entrepreneurial orientation will exhibit stronger performance as a result of balancing proximity to the university compared to spin-offs with low entrepreneurial orientation.

This study posits that spin-offs facing high market hostility may be prepared to address such problems after graduating from incubators by maintaining proximity to the university (Bengtsson and Solvell, 2004). This strategic option may result in stronger performance compared to spin-offs facing low market hostility. Extending this line of argument, the present study examines the moderating role of market hostility in the proposed curvilinear proximity- 
performance relationship. We predict that for spin-offs with high market hostility, the ability to balance proximity will have a positive effect on performance. In contrast, there is a lesser requirement for spin-offs facing low market hostility to maintain proximity to the university due to having many different strategic options.

For this reason, we predict that the curvilinear relationship between proximity and performance for spin-offs with strong market hostility is steeper than for spin-offs facing less market hostility. Growth in these environments is at times a zero-sum game, insofar as growth is primarily achieved by taking a market share from rivals (Porter, 1996). Thus, increasing proximity to the university may not yield the same profit and growth outcomes achieved under low hostility (i.e., in placid environments). Balancing proximity is essential for the growth of spin-offs facing high market hostility. First, as competition intensifies, spin-offs need high quality innovative information to provide effective competitive responses. Obtaining such information without the university's ties is unlikely, since universities stay up-to-date, proactively search for and acquire knowledge from their continuous research activities. Second, a hostile market compels spin-offs to act quickly to adapt to the new rules of the game. By establishing a balanced proximity with universities, spin-offs have a greater propensity to collaborate to access important resources that are unavailable to their competitors. At the same time, spin-offs have their own resources to maintain access to information from other sources outside the university. In sum, whereas market hostility strengthens the positive effect of proximity by providing a safe haven during turbulent times, this is only the case when spinoffs are able to balance proximity to the university. Therefore, we predict the following hypothesis:

H7. Market hostility moderates the inverted U-shaped relation between proximity and performance such that spin-offs with high market hostility will exhibit stronger performance as a result of balancing proximity to the university compared to spin-offs with low market hostility.

\section{Research method}

The sample was constituted by university spin-offs of Delft University of Technology DUT (the Netherlands) and the Norwegian University of Science and Technology - NTNU (Norway). By examining university spin-offs from both universities, we aimed to widen our research by covering the phenomenon in different contexts while maintaining consistency in selecting samples for this research. The Netherlands and Norway are similar in terms of their 
entrepreneurial attitudes and perceptions (Global Entrepreneurship Monitor, 2017) which reduces the chance of bias. In addition, both universities also share similar characteristics in terms of resource outputs and types of faculties, and are known as two of the best technical universities in Europe. Both have some specialization in maritime sectors (sea-transport; mining, oil/gas and wind-energy production at sea), civil engineering and electrical engineering, and related activities (manufacturing and information services). Both are also historical universities, going back to important foundation decisions in 1842 (DUT) and 1870 (NTNU). At a close distance to the two universities, there are important organizations of applied research (TNO in the Netherlands and SINTEF in Norway), bridging a close distance between the universities' research activities and real industrial applications.

This study was conducted in several stages to deal with the causality issues. The first survey started in 2007, the second in 2010 and the third in 2013. To pre-test the first survey and ensure that our questions were clear, we conducted informal interviews with two academics in entrepreneurship studies and three founders of university spin-offs before administrating the final version. We asked them to point out ambiguous, vague, and unfamiliar terms, and incorporated their feedback to improve the survey's validity, readability and relevance (Podsakoff et al., 2003).

The original sample (2007) was built as follows. From the database maintained by the incubators and the university departments involved, we obtained around 150 names of spinoffs that received support and were not older than 10 years (in 2007). From this database, we selected spin-offs that had completed incubation programs, meaning they were accommodated for more than 3 years in the university incubators, or had received alternative university support, e.g. accommodation in rooms at the faculty. This resulted in a database of 115 spinoffs. Fifteen firms failed to respond to our invitation, five of which had gone out of business. The final sample therefore consisted of 100 university spin-offs (overall rate 87\%).

In the second stage (2010-2011), we followed the same procedure and the data was collected repeating the same questions but with a greater focus on performance. Although we received responses from 127 university spin-offs in total, only those that had participated in the first stage of the study were considered. Thus, we maintained the sample of 100 university spinoffs. By having two sets of responses, we were able to reduce the potential bias created by episodic growth and to gather performance data in a more stable and consistent way. To control for nonresponse bias, we tested any significant differences between the first and the second survey. Since we found that no such differences emerged, nonresponse bias was not an issue (Armstrong and Overton, 1977). 
The final data collection was conducted in 2013. The process of data collection ran until $2016 / 2017$. Unfortunately, the response rate was relatively low (60\%). In this stage, some interviews (qualitative research) were collected to increase the depth of the analysis. This study presents the results of statistical analysis based on the second stage data collection (2010-2011) as it has better fit to the model.

\subsection{Variables and measures}

\subsubsection{Dependent variable}

Spin-off performance. Entrepreneurship literature states that measuring the performance of small firms is a difficult task. Previous studies use a variety of measurements including growth (job growth), financial measure (sales, turnover), and owner's subjective evaluation of performance. Some studies argue that growth as a measure of performance is more accurate and accessible than accounting measures of financial performance (Brush and Vanderwerf, 1992; Chandler and Hanks, 1993). However, firms may choose to trade-off long-term growth for short-term profitability (Zahra, 1991). Moreover, as the performance of small firms can be described as multidimensional in nature, integrating different dimensions of performance in empirical studies is advantageous. Capturing the different aspects of small business performance requires a combined measure of financial performance and growth.

Using data collected between 2010-2011, we used self-reported measures of gross margin, profitability, and cash flow relative to competitors to measure financial performance. Respondents were asked to state their last two year's profits and sales, while gross margin was calculated as the ratio of gross profits to sales. For the other financial performance measures, the respondents were asked to estimate profit and cash flow compared to competitors on a fivepoint scales ranging from "much worse than our competitors" to "much better than our competitors". For growth, we used four indicators. In each survey round, the respondents were asked to state the previous year's sales and current number of full-time equivalents. Sales and employee growth were calculated as the ratio of the change in size (in a one-year period) and the size at the time of the first survey. Five-point scales were used to measure sales and employee growth relative to competitors, anchored to "much less than our competitors" and "much more than our competitors". The financial performance and growth measures were standardized and then combined. In this process, we transformed the ratio of gross profit, percentage of sales, and job growth into a 5-point scale. The Cronbach alpha for this global performance index is .70 which is well accepted. 


\subsubsection{Independent variables}

Research-oriented spin-offs. This variable was measured using a dichotomous variable expressing the presence of an academic founder who actively continues research activities. Academic founders are defined as university staff (professor, research associate, post-doctoral researcher) with a full- or part-time position at the university when the business started. We argue that by having a position at the university, academic founders will influence the strategic direction of spin-offs in terms of maintaining research activities. Spin-offs with one or more of such academic founders are indicated with 1, otherwise 0 .

Entrepreneurial orientation. To operationalize the entrepreneurial orientation dimensions, we built on the established Covin and Slevin (1989) scale, which includes innovativeness, risktaking, and proactiveness. Innovativeness reflects the tendency to actively support new ideas, novelty, experimentation, and creative solutions in pursuit of competitive advantage. Risktaking involves a tendency to take business-related risks in terms of strategic actions in uncertain environments. Proactiveness denotes a tendency to anticipate and act on future needs by introducing new products and services ahead of the competition (Covin and Slevin, 1989, Lumpkin and Dess, 1996). As the original scale referred to established firms, we adjusted some items to the context of spin-offs. We then factor-analysed the items to confirm the original three-factor solution. After dropping items with a factor loading of less than .40 - a common rule of thumb (e.g., Schumacker and Lomax, 2004) - the three dimension of innovativeness (2 items), proactiveness ( 3 items), and risk-taking ( 2 items) emerged, with alpha levels of .75, .64, and .70 respectively. Although the Average Variance Extracted (AVE) of proactiveness (.44) was lower than the desired .50, the Composite Reliability exceeded the recommended threshold of .60. Moreover, the test that Fornell and Larcker (1981) recommend confirmed the discriminant validity of our scales. The sum of the three dimensions forms the final measure for entrepreneurial orientation. Higher scores on the scale indicate a more entrepreneurial orientation, and lower scores a more conservative orientation.

Market hostility. This variable was adapted from the three-item scale developed by Khandwalla (1976) and Covin and Slevin (1989) for the academic context. The respondent ratings on these three items were averaged to arrive at a single market hostility index for each spin-off. The higher the index, the more hostile the firm's environment. This scale has a mean of 4.13 , a standard deviation of 1.56 , a range of 1.90 to 7.0 , and an inter-item reliability coefficient of 0.70 . While spatial proximity and social proximity act as dependent variables in relationships in hypotheses 1 to 3, they act as independent variables and moderated variables in hypotheses 4 to 7 . 
Spatial proximity. This factor was measured by asking each respondent about travel time between the spin-off and the university. The data was also validated by measuring the spatial distance between the spin-off's office location and the university. As the data of this study was collected in two locations, we also consider the geographical context. Delft is located in a highly urbanised area in the western part of the Netherlands (Randstad), while Trondheim is in the centre of Norway, at a distance of several hundred kilometres from other cities, like Bergen and Oslo. However, as we compared the travel distances, we found similar results where most of their spin-offs were located close to the university or surrounding regions. In the few cases in which large distances in Norway were involved, travel time relates to travelling by airplane. In addition, despite smaller agglomeration advantages in Trondheim, as theory would suggest, the growth patterns of university spin-offs turned out to be similar (Soetanto and Geenhuizen, 2009). On average, the spin-offs, after ending incubation support, are at 36 minutes' travel distance from university. The relatively large standard deviation of 16 suggests some larger travel time and distances involved in Norway, like those caused by a relocation from Trondheim to Bergen and to the Oslo region.

Social proximity. To measure social proximity, the variable of strength of ties was constructed from the frequency of face-to-face interactions between the spin-offs and their network contacts. We asked respondents about the number of interactions they had with each of their partners on a monthly basis. A high value indicates a relatively strong relationship (min: 0; max: 1). Using the number of contacts (n) and frequency of interactions (i), we constructed the formula of frequency of interaction as follows:

$$
f=\frac{\sum_{t=1}^{n} i_{t}}{n}
$$

In measuring the strength of ties, we collected data on the spin-offs' social networks according to an existing network approach (e.g., Burt, 2004; McEvily and Zaheer, 1999) by asking the respondents to indicate their most important contacts who were willing to help by offering them access to resources, knowledge, and information. In this study, a limit of ten people was set in the identification of partners that were most prominent to the spin-offs.

As we also inquired about the background of each contact, we could identify the number of university contacts and the frequency of interaction. For spin-offs established by more than one founder, an interview was conducted with the founders when possible. Validation from other founders is important, as we did not aim to capture their personal network. Instead, we intended 
to construct the spin-offs' supporting networks relevant on the firm level. The mean score on social proximity is 0.46 with quite some variation (standard deviation of 0.24 ).

\subsubsection{Control variables}

Size of founding team. This variable was included as a control variable due to the significant association between it and performance (Zahra, 1993). A positive relationship is expected between size of founding team and performance, since larger spin-offs are assumed to possess slack resources that allow them to exploit market opportunities, solve problems, and deal with sudden environmental changes. The variable is described as the number of founders.

Spin-off age. This variable was measured as the number of years since establishment. Spinoffs may have better opportunities to grow if they are able to learn from previous experiences (Jovanovic, 1982). When spin-offs become older, they improve their ability to effectively meet objectives.

Level of innovativeness. This variable was measured as the number of patented products. We expect that spin-offs with a high level of innovativeness are more associated with proximity to the university.

\section{Results}

\subsection{Determinant factors of spatial and social proximity}

Table 1 reports the descriptive statistics and the correlation among the study's variables. First, some remarks about the correlation between physical and social proximity: a positive relation is found between the two proximities, although the correlation is not strong $(0.20)$. Further, the first three rows consist of control variables, followed by the spatial proximity and social proximity variables, and several independent and dependent variables. As Table 1 shows, these have some positive and negative correlations with other variables. For the control variables, the spin-off age variable does not show any correlation with the others, while the innovativeness and size of the founding team variables are correlated to the other variables. Spin-offs with high levels of innovativeness are correlated to the research-oriented spin-offs, entrepreneurial orientation (EO), and market hostility variables. The size of the founding team is positively related to social proximity. This finding is interesting and unexpected. It may be that spin-offs with more founders have greater opportunities to maintain social ties at the university. Moreover, social proximity is also correlated to spatial proximity, meaning that the shorter the physical distance, the stronger the social relationship. While this outcome is accepted in 'traditional' urban economics and innovation studies, an upcoming stream of 
studies in 'relational' geography states that spatial proximity is not necessarily needed to establish and maintain social relations, as these can also be extended over larger distances if the partners speak the same language and have a similar culture (Breschi and Lissoni, 2001; Ertur and Koch, 2011; Maggioni and Uberti, 2009; Ponds et al., 2007). Moreover, we also find a correlation between research-oriented spin-offs and social proximity, while market hostility encourages spin-offs to be located spatially close to the university.

Table 1 here

To test H1, H2, and H3, we ran a regression analysis with spatial and social proximity as the dependent variables (Table 2). In H1, we predict a relationship between research-oriented spin-offs and maintaining proximity to the university after leaving the incubator. The finding confirms the hypothesis as the variable shows positive and significant signs for both regressions. If researchers involved in the spin-off's founding team also work at the university part-time this encourages spin-offs to maintain both spatial and social proximity to the university. Moreover, the finding partially confirms H2, showing that the EO variable is only significant when social proximity acts as a dependent variable, suggesting a trend that spinoffs with high entrepreneurial orientation maintain strong relationships with academics without being located close to the university. It may be the case that these spin-offs moved their offices to be closer to the market (launching customer) or for a better (mature) office environment, yet maintain social ties for further exploration and exploitation of the university's knowledge and research. Moreover, as predicted, spin-offs facing strong market hostility maintain proximity to the university. $\mathrm{H} 3$ is thus supported in the case of spatial proximity as a dependent variable, but not in the case of social proximity. In our cases, we find that some academic entrepreneurs still maintain their position at the university, which makes it convenient to have an office located close to the university, or they receive support from their research group, such as having an office on the university's premises, without having intensive interaction. From the perspective of responding to a hostile market forces, the university spin-offs may prefer a relatively cheap location solution after incubation, to be able to spend more resources to defend and improve their market position.

Table 2 here 
Table 3 presents the results of the moderated hierarchical regression analysis used to test H4. After centring our independent variables (Aiken et al., 1991), we introduced these into a regression equation including the control variables, the main effect variable, and the quadratic term of spatial and of social proximity. The findings indicate support for $\mathrm{H} 4$ stating that either spatial or social proximity has an inverted U-shaped relationship with performance. It would seem there is an optimum point of proximity to the university where maintaining a high level of proximity will result in diminishing returns of performance. The curvilinear relationship trend tends to be consistent for spatial and social proximity as the variable of their squared terms is negative and significant. Note that Model 4 - including the squared term of social proximity - is relatively strong in explaining variance in performance among the spin-offs (adjusted $\mathrm{R}^{2}$ 0.44).

Table 3 here

$\mathrm{H} 5$, H6, and $\mathrm{H} 7$ predicted that the relationship between proximity and performance is moderated by certain factors, namely, research orientation, entrepreneurial orientation, and market hostility. To test these hypotheses, we introduced the interaction term between the variable of each factor with either the spatial or social proximity variable (Table 4). In addition, we also considered the quadratic term of the spatial and social proximity variables.

With regard to spatial proximity, a significant result is only found for the interaction between spatial proximity and entrepreneurial orientation. Similarly, social proximity shows significant results. The findings show that the inverted U-shaped relationship between spatial and social proximity and performance is moderated by the entrepreneurial orientation variable. Under the condition of intermediate social ties, spin-offs with higher entrepreneurial orientation show higher performance than those with lower entrepreneurial orientation.

Except for some moderating influence of market hostility, the most convincing moderating influence between proximity and performance is that of entrepreneurial orientation, both in a linear and a 'decreasing returns' relationship. This would mean that distances to university and interaction with them most often matter according to entrepreneurial orientation of the spinoffs, and that entrepreneurial universities acting critically in terms of enabling close proximity and interaction, mainly do that for spin-offs that take risks and are pro-active. For illustration, the moderation and the curvilinear relationship are shown in the appendix. 
Table 4 here

\section{Discussion}

\subsection{Theoretical findings: hypotheses testing}

Table 5 summarises the results of our hypotheses testing. The study finds that researchoriented spin-offs tend to develop both spatial and social proximity to the university. For these spin-offs, access to university facilities and research is still critical for post-incubation activities. Highly entrepreneurial spin-offs, as shown by the findings, maintain social proximity to the university. Interestingly, these spin-offs may not be located at the same site as their universities, but they preserve social relationships with their contacts there. The findings show that the role of the university is still relevant in supporting the long-term growth of spin-offs. Spin-offs with a highly entrepreneurial orientation may keep coming back to the university to find opportunities based on technology and innovation. In particular spin-offs facing market hostility are more likely to be located close to the university. This finding may suggest that university support - such as access to researchers, funding and facilities - is still needed after incubation, at low cost during turbulent times. Overall, as the risk in bringing a new technology or invention into the market is relatively high, universities should extend their support beyond the incubation period, especially for spin-offs facing a hostile market environment.

\section{Table 5 here}

Further results point out that both spatial and social proximities have negative effects on performance when the level of proximity is too close or the ties are too strong. This finding is crucial as it reveals how current policies, which intend to attract firms to stay in the region and contribute to the local economy, may have a potential downside. It is important for policies to encourage spin-offs to be independent while at the same time, the provided support should not be overprotective on spin-offs. As committing to a relationship needs resources, overmaintaining a relationship with the university may prevent spin-offs from using their resources for other activities, such as expanding markets and developing customer relations. Moreover, we also find that entrepreneurial orientation moderates the relationship between proximity to university and performance. In this case, spin-offs with high entrepreneurial orientation that 
are able to develop balanced proximity are likely to benefit from proximity to the university. These spin-offs have strong potential, as they are willing to continue to grow in the postincubation time. In our research, we found some evidence where the university provides abundant opportunities for spin-offs after graduating from incubators, for example, as a source of new (tacit) knowledge, access to advanced equipment, access to creative students, a source of income in externally financed research projects, and access to testing in real life conditions (see appendix). However, being exposed to many options creates difficulties in making decisions and selecting the best potential opportunities.

\subsection{Practical findings: spin-offs' characteristics and the supports by entrepreneurial universities}

The study found that there are several reasons for maintaining proximity after graduating from incubators. First, these spin-offs benefit from close collaboration with university employees in research and technology transfer, like in EU research programs, such as Framework 7 or Horizon2020. Secondly, founders of research-oriented spin-offs who work full or part-time at the university, create network inertia that requires spin-offs to stay in proximity to it. Third, access to a pool of creative students as one of the permanent 'attractors' of the university. Fourth, spin-offs also benefit from the university as a testing ground for their technology solutions.

In the appendix, we provide an illustration about three university spin-offs and their types of relationship with the university. Entrepreneurial universities are active in the creation and 'nurturing' of university spin-offs, yet it is not known whether support should be continued in the post-incubation stage. Based on those findings, this study brought to light that university incubation support needs to be continued for particular spin-off segments in view of contribution to the (regional) economy, in various 'subtle' ways:

- Proximity-related support (accommodation, facilities) tends to be important for performance of research-oriented spin-offs and for spin-offs facing market hostility.

- Social interaction support (access to networks) tends to be important for performance of research-oriented spin-offs and for entrepreneurial-oriented spin-offs.

- Extending support may leads to a negative influence on performance among all spinoff segments.

- Only spin-offs with high entrepreneurial orientation and ability to create balance in using proximity and social interaction-related support, have a strong potential to grow and contribute to economic growth. 


\section{Conclusion}

Entrepreneurial universities are deemed an engine of economic growth where creating university spin-offs is a valued mechanism. Numerous policies have been developed in support of incubators at universities to encourage the development of their spin-offs (Urbano and Guerrero, 2013). While much attention is paid to the creation process and the early growth of these spin-offs, studies on life after incubation are still limited. However, this should not discourage scholars from opening a new discussion on the nature of the post-incubation relationship between universities and their spin-offs. In the context of an entrepreneurial university, this question is critical to their strategy in strengthening their role as an economic and societal change agent. Focusing heavily on the early stage of spin-offs' creation without considering the long-term performance may have a detrimental effect on sustaining the role of universities in (regional) economic growth. More studies are needed to guarantee survival and the long-term growth of university spin-offs and to reveal the true benefits of incubators and incubation programs (Pena, 2004; Rothaermel and Thursby, 2005; Van Weele et al., 2017). Our study contributes to developing understanding of university spin-offs' growth by investigating the motivation of spin-offs to maintain proximity to the university in their postincubation years. It appears that spatial and social proximity is still important for spin-offs in those later years, however, in a differentiated pattern and following an inverted U-shaped relationship.

This study has theoretical and practical contributions. In terms of theoretical contribution, it adds to research on small firm organisational change. Despite the considerable attention to organisational change in the literature, significant gaps persist in understanding how small firms respond to environmental changes. Research efforts in this large body of literature focus almost exclusively on large well-established firms, and market or technology changes. Studies focusing on small firms, especially on the life of university spin-offs after incubation, are scarce. In fact, emerging studies report that the growth of university spin-offs is not as strong as initially thought (Mustar et al., 2008; Tavoletti, 2013; van Weele et al., 2017). It would seem that spin-offs struggle after incubation where most are not yet able to develop capabilities and achieve the 'business platform' level, a state where an entrepreneurial firm has the capability to grow (Davidsson and Klofsten, 2003; Klofsten, 2010). Moreover, van Geenhuizen and Soetanto's (2013) study on university spin-offs from technical universities in Europe finds that obstacles faced by spin-offs increase in the year after ending participation in incubation programs, indicating a negative effect of environmental change and providing an explanation 
for the rather disappointing performance of European university spin-offs. The study found that leaving the incubator does not end the relationship between universities and their spinoffs. Challenges and organisational inertia after moving out from incubators may force spinoffs to stay close to the university or maintain social ties with university academic staff.

In the context of entrepreneurial university, two important practical contributions can be offered from this study. First, when addressing the issue of how to respond to the key strategic challenge for the entrepreneurial university to drive economic growth and social change, it is important to develop a differentiated approach in supporting spin-offs in the longer term. Entrepreneurial universities should encourage university spin-offs not only to stay in the region but also help them to grow. As the findings have suggested, only specific segments of spinoffs benefit from post-incubation proximity and social interaction support, requiring 'subtle' matches between spin-offs' needs and supply incubator support, including flexibility. The last would mean that incubators do not offer a full plan that is obligatory to follow but a plan that avoids over-support (given what spin-offs can manage and absorb). In some cases, this is only the access to the incubator's facilities and networks, without being located close to the university. Maintaining too close relationships and proximities may create a negative impact on the performance of the university spin-offs. Policy makers at entrepreneurial universities should be aware of this double-edged sword effect of their support. Consequently, a new kind of policy needs to be developed in order to minimise the negative impact and at the same time ensure growth.

Second, the findings reveal that university spin-offs with high entrepreneurial orientation will benefit from a balanced proximity to university. Support policies need to be directed to target such spin-offs as they show a strong post-incubation growth. This encourages universities and incubators to identify their highly entrepreneurial spin-offs and create tailored support to ensure their growth needs are met. This segment may not need to be spatially close to the university, but needs to be actively informed on progress and partnering in the university's research to further commercialise research. Through this type of engagement, entrepreneurial universities may benefit from greater knowledge-commercialisation activities and, in turn, contribute to economic growth. This finding also shows the importance of interacting with graduated spin-offs. Successful university spin-offs can be local champions and help the creation of new start-ups while at the same time help to sustain a healthy business ecosystem by connecting relevant actors (van Geenhuizen, 2016; Hayter, 2016). Moreover, due to the need for resources in supporting post-incubation spin-offs, it is recommended that universities broaden their collaboration and invite other players to provide support or work 
with these spin-offs. As shown by the finding that spin-offs need to maintain proximity to the university, this creates a benefit for both sides in terms of knowledge exchange and technology transfer.

Like much empirical research, our study has some limitations. A first limitation stems from the method of identifying proximity. We use travel time and a social network measurement, namely, strength of ties (Burt, 2004). In investigating the social proximity of spin-offs, we interviewed respondents by asking them about their main contacts. Although this implies a limitation in the coverage of networks, it also focuses on those networks that really matter. Second, while we evaluated the impact of proximity on performance, and explored the presence of decreasing returns and lock-in effects on performance, the relationship between the university and spin-offs is clearly more complex than this. Despite the presence of a curvilinear relation of proximity and performance, the impact of proximity can also be translated into other forms, such as spin-off innovation activities, founders' personal relationship, and well-being. Future studies could complement the current research by investigating different types of performance as a result of being proximate to universities. Third, given the specific situation of spin-offs, we faced limitations in selecting a sample for this study. The empirical study was carried out in the Netherlands and Norway, and focusses on technical universities where most spin-offs are technology-based. This selection may have some implications on the generalisation of our findings, which may hold only for technical universities in Europe with a similar entrepreneurial and innovation culture, and a similar focus on maritime-oriented and related sectors. This situation calls for future research at general universities, in other sectors, and other regions to enable the picture to be completed.

Moreover, future research needs to investigate the impact of a university's expansion on its entrepreneurship activities. In responding to new market changes and new segments of students, the two universities in this study have taken decisions that may affect both patterns of spatial proximity and social proximity. In early 2016 NTNU merged with three university colleges, of which two are at a distance in other regions in Norway: University College Álesund and University College Gjøvik. Aside from mergers, new campuses may be established, like DUT did in early 2017 in the adjacent and much larger city of The Hague, starting in existing buildings of the University of Leiden. While the emphasis on education and research may differ between the campuses, their very presence opened new and varied sets of physical and social proximities, and new opportunities for university spin-offs. For example, the campus in The Hague offers potentials for accessing new fields like peace, safety and security. As a result, 
multi-site campuses may reinforce positive influence in more than one region or city. Such changes deserve separate attention in future research.

\section{References}

Aiken, L.S., West, S.G., Reno, R.R., 1991. Multiple regression: Testing and interpreting interactions. Sage.

Amburgey, T. L., Rao, H., 1996. Organizational ecology: Past, present, and future directions. Academy of Management Journal 39(5), 1265-1286.

Amezcua, A.S., 2010. Performance analysis of entrepreneurship policy: which business incubators generate the highest levels of economic performance? Frontiers of Entrepreneurship Research 30(18).

Argote, L., Miron-Spektor, E., 2011. Organizational learning: From experience to knowledge. Organization science 22(5), 1123-1137.

Armstrong, J.S., Overton, T.S., 1977. Estimating nonresponse bias in mail surveys. Journal of Marketing Research 396-402.

Arthur, W.B., 1994. Increasing returns and path dependence in the economy. University of Michigan Press.

Barney, J.B., Clark, D.N. 2007. Resource-based theory: Creating and sustaining competitive advantage. Oxford, UK: Oxford University Press.

Baum, J.A., Calabrese, T., Silverman, B.S., 2000. Don't go it alone: Alliance network composition and startups' performance in Canadian biotechnology. Strategic Management Journal 267-294.

Bathelt, H., Kogler, D. F., Munro, A. K., 2010. A knowledge-based typology of university spin-offs in the context of regional economic development. Technovation 30(9), 519532.

Bengtsson, M., Sölvell, Ö., 2004. Climate of competition, clusters and innovative performance. Scandinavian Journal of Management 20(3), 225-244.

Benneworth, P., Charles, D., 2005. University spin-off policies and economic development in less successful regions: learning from two decades of policy practice. European Planning Studies 13(4), 537-557.

Boschma, R., 2005. Proximity and innovation: a critical assessment. Regional Studies 39(1), 61-74.

Breschi, S., Lissoni, F., 2001. Knowledge spillovers and local innovation systems: a critical survey. Industrial and Corporate Change 10(4), 975-1005.

Brouthers, K.D., Brouthers, L.E., Werner, S., 1996. Dunning's eclectic theory and the smaller firm: The impact of ownership and locational advantages on the choice of entry-modes in the computer software industry. International Business Review 5(4), 377-394.

Brush, C.G., Vanderwerf, P.A., 1992. A comparison of methods and sources for obtaining estimates of new venture performance. Journal of Business Venturing 7(2), 157-170.

Bruton, G.D., Ahlstrom, D., 2003. An institutional view of China's venture capital industry: Explaining the differences between China and the West. Journal of Business Venturing 18(2), 233-259.

Burt, R.S., 2004. Structural holes and good ideas 1. American Journal of Sociology 110(2), 349-399.

Chandler, G.N., Hanks, S.H., 1993. Measuring the performance of emerging businesses: A validation study. Journal of Business Venturing 8(5), 391-408.

Chattopadhyay, P., Glick, W. H., Huber, G. P., 2001. Organizational actions in response to threats and opportunities. Academy of Management Journal 44(5), 937-955. 
Clark B. 2001, The Entrepreneurial University: New Foundations for Collegiality, Autonomy, and Achievment, Higher Education Management 13 (2).

Clarysse, B., Wright, M., Lockett, A., Van de Velde, E., Vohora, A., 2005. Spinning out new ventures: a typology of incubation strategies from European research institutions. Journal of Business Venturing 20(2), 183-216.

Clarysse, B., Tartari, V., Salter, A., 2011. The impact of entrepreneurial capacity, experience and organizational support on academic entrepreneurship. Research Policy, 40(8), 1084-1093.

Cooke, P., 2001. Regional innovation systems, clusters, and the knowledge economy. Industrial and Corporate Change 10(4), 945-974.

Covin, J.G., Slevin, D.P., 1989. Strategic management of small firms in hostile and benign environments. Strategic Management Journal 10(1), 75-87.

Davidsson, P., \& Klofsten, M. (2003). The business platform: Developing an instrument to gauge and to assist the development of young firms. Journal of small business management, 41(1), 1-26.

Duranton, G., Puga, D., 2004. Micro-foundations of urban agglomeration economies. Handbook of Regional and Urban Economics 4, 2063-2117.

Dyer Jr, W. G., 1994. Toward a theory of entrepreneurial careers. Entrepreneurship: Theory and Practice 19(2), 7-22.

Egeln, J., Gottschalk, S., Rammer, C., 2004. Location decisions of spin-offs from public research institutions. Industry and innovation 11(3), 207-223.

Elfring, T., Hulsink, W., 2003. Networks in entrepreneurship: The case of high-technology firms. Small Business Economics 21(4), 409-422.

Ertur, C., Koch, W., 2011. A contribution to the theory and empirics of Schumpeterian growth with worldwide interactions. Journal of Economic Growth 16(3), 215-255.

Escribano, A., Fosfuri, A., Tribó, J.A., 2009. Managing external knowledge flows: The moderating role of absorptive capacity. Research Policy 38(1), 96-105.

Fayolle, A., \& Redford, D. T. 2015. Introduction: Towards More Entrepreneurial Universities - Myth or Reality? In A. Fayolle \& D. T. Redford (Eds.), Handbook on the Entrepreneurial University: 1-8. Cheltenham: Edward Elgar Publishing Limited.

Feldman, M. S., Pentland, B. T., 2003. Reconceptualizing organizational routines as a source of flexibility and change. Administrative Science Quarterly 48(1), 94-118.

Fini, R., Grimaldi, R., Santoni, S., Sobrero, M., 2011. Complements or substitutes? The role of universities and local context in supporting the creation of academic spinoffs. Research Policy 40(8), 1113-1127.

Fornell, C., Larcker, D.F., 1981. Structural equation models with unobservable variables and measurement error: Algebra and statistics. Journal of Marketing Research, 382-388.

Global Entrepreneurship Monitor (GEM), 2017. Global Report 2016/2017. GERA.

Grabher, G., 1993. The weakness of strong ties; the lock-in of regional development in the Ruhr Area. In: Grabher, G. (Ed) The embedded firm. On the socioeconomics of industrial networks, Routledge, London New York, pp 255-277.

Grinstein, A., 2008. The effect of market orientation and its components on innovation consequences: a meta-analysis. Journal of the Academy of Marketing Science 36(2), 166-173.

Guerrero, M., Urbano, D. 2012. The development of an entrepreneurial university. The journal of technology transfer 37(1), 43-74.

Guerrero, M., Urbano, D. 2014. Academics' start-up intentions and knowledge filters: An individual perspective of the knowledge spillover theory of entrepreneurship. Small Business Economics, 43(1), 57-74. 
Guerrero, M., Urbano, D., Fayolle, A. 2016. Entrepreneurial activity and regional competitiveness: evidence from European entrepreneurial universities. The Journal of Technology Transfer 41(1), 105-131.

Gulati, R., Higgins, M.C., 2003. Which ties matter when? The contingent effects of interorganizational partnerships on IPO success. Strategic Management Journal 24(2), 127-144.

Hannan, M.T., Freeman, J., 1984. Structural inertia and organizational change. American Sociological Review, 149-164.

Hayter, C.S., 2016. A trajectory of early-stage spin-off success: the role of knowledge intermediaries within an entrepreneurial university ecosystem. Small Business Economics 47(3), 633-656.

Hrebiniak, L.G., Joyce, W.F., 1985. Organizational adaptation: Strategic choice and environmental determinism. Administrative Science Quarterly, 336-349.

Johansson, M., Jacob, M., Hellström, T., 2005. The strength of strong ties: University spin-offs and the significance of historical relations. The Journal of Technology Transfer 30(3), 271-286.

Jovanovic, B., 1982. Selection and the Evolution of Industry. Econometrica: Journal of the Econometric Society, 649-670.

Katila, R., Rosenberger, J.D., Eisenhardt, K.M., 2008. Swimming with sharks: Technology ventures, defense mechanisms and corporate relationships. Administrative Science Quarterly 53(2), 295-332.

Keeble, D., Wilkinson, F. (Eds.). 2000. High-technology clusters, networking and collective learning in Europe. Ashgate Publishing.

Khandwalla, P.N., 1976. The techno-economic ecology of corporate strategy. Journal of Management Studies 13(1), 62-75.

Kiesler, S., Sproull, L., 1982. Managerial response to changing environments: Perspectives on problem sensing from social cognition. Administrative Science Quarterly 548-570.

Klofsten, M., 2010. The business platform, Entrepreneurship and management in the early stages of a firm's development, TII asbl: Aldingen, Luxembourg.

Lant, T.K., Milliken, F.J., Batra, B., 1992. The role of managerial learning and interpretation in strategic persistence and reorientation: An empirical exploration. Strategic Management Journal 13(8), 585-608.

Lasrado, V., Sivo, S., Ford, C., O’Neal, T., Garibay, I., 2016. Do graduated university incubator firms benefit from their relationship with university incubators? The Journal of Technology Transfer 41(2), 205-219.

Laukkanen, M., 2000. Exploring alternative approaches in high-level entrepreneurship education: creating micromechanisms for endogenous regional growth. Entrepreneurship \& Regional Development 12(1), 25-47.

Levinthal, D., March, J.G., 1981. A model of adaptive organizational search. Journal of Economic Behavior \& Organization 2(4), 307-333.

Levitt, B., March, J. G., 1988. Organizational learning. Annual review of sociology 14(1), 319338.

Lockett, A., Wright, M., 2005. Resources, capabilities, risk capital and the creation of university spin-out companies. Research Policy 34(7), 1043-1057.

Liao, S. H., Fei, W. C., Liu, C. T., 2008. Relationships between knowledge inertia, organizational learning and organization innovation. Technovation 28(4), 183-195.

Lumpkin, G.T., Dess, G.G., 1996. Clarifying the entrepreneurial orientation construct and linking it to performance. Academy of Management Review 21(1), 135-172. 
Lundvall, B.Å., Joseph, K.J., Chaminade, C., Vang, J., (Eds). 2011. Handbook of innovation systems and developing countries: Building domestic capabilities in a global setting. Edward Elgar Publishing.

Maggioni, M.A., Uberti, T.E., 2009. Knowledge networks across Europe: Which distance matters? The Annals of Regional Science 43(3), 691-720.

March, J.G., Simon, H.A., 1958. Organizations.

Maskell, P., Malmberg, A., 1999. Localised learning and industrial competitiveness. Cambridge Journal of Economics, 167-185.

Maurer, I., Ebers, M., 2006. Dynamics of social capital and their performance implications: Lessons from biotechnology start-ups. Administrative Science Quarterly 51(2), 262292.

McAdam, M., Galbraith, B., McAdam, R., Humphreys, P., 2006. Business processes and networks in university incubators: A review and research agendas. Technology Analysis \& Strategic Management 18(5), 451-472.

McEvily, B., Zaheer, A., 1999. Bridging ties: A source of firm heterogeneity in competitive capabilities. Strategic Management Journal, 1133-1156.

McGrath, R. G., 1999. Falling forward: Real options reasoning and entrepreneurial failure. Academy of Management Review 24(1), 13-30.

Mian, S.A., 1996. Assessing value-added contributions of university technology business incubators to tenant firms. Research Policy 25(3), 325-335.

Mian, S. A. 1994. US university-sponsored technology incubators: an overview of management, policies and performance. Technovation 14(8), 515-528.

Miller, D., Friesen, P.H., 1983. Successful and unsuccessful phases of the corporate life cycle. Organization Studies 4(4), 339-356.

Miller, D., Shamsie, J., 1996. The resource-based view of the firm in two environments: The Hollywood film studios from 1936 to 1965. Academy of Management Journal 39(3), 519-543.

Morgan, K., 2004. The exaggerated death of geography: learning, proximity and territorial innovation systems. Journal of Economic Geography 4(1), 3-21.

Mustar, P., 1997. How French academics create hi-tech companies: the conditions for success or failure. Science and Public Policy 24(1), 37-43.

Mustar, P., Renault, M., Colombo, M.G., Piva, E., Fontes, M., Lockett, A., Moray, N., 2006. Conceptualising the heterogeneity of research-based spin-offs: A multi-dimensional taxonomy. Research Policy 35(2), 289-308.

Mustar, P., Wright, M., Clarysse, B., 2008. University spin-off firms: lessons from ten years of experience in Europe. Science \& Public Policy (SPP) 35(2).

Muzzi, C., Albertini, S., 2015. Communities and managerial competencies supporting SMEs innovation networking: a longitudinal case study. R\&D Management 45(2), 196-211.

Narula, R., 2002. Innovation systems and 'inertia'in R\&D location: Norwegian firms and the role of systemic lock-in. Research policy 31(5), 795-816.

Ndonzuau, F.N., Pirnay, F., Surlemont, B., 2002. A stage model of academic spin-off creation. Technovation 22(5), 281-289.

Nelson, R. R. (Ed). 1993. National innovation systems: a comparative analysis. Oxford University Press.

Nosella, A., Grimaldi, R., 2009. University-level mechanisms supporting the creation of new companies: an analysis of Italian academic spin-offs. Technology Analysis \& Strategic Management 21(6), 679-698.

Pena, I., 2004. Business incubation centers and new firm growth in the Basque country. Small Business Economics 22(3-4), 223-236. 
Pirnay, F., Surlemont, B., 2003. Toward a typology of university spin-offs. Small Business Economics 21(4), 355-369.

Pirnay, F., Surlemont, B., Nlemvo, F., 2003. Toward a typology of university spin-offs. Small business economics 21(4), 355-369.

Podsakoff, P.M., MacKenzie, S.B., Lee, J.Y., Podsakoff, N.P., 2003. Common method biases in behavioral research: a critical review of the literature and recommended remedies. Journal of Applied Psychology 88(5), 879.

Pollock, T.G., Gulati, R., 2007. Standing out from the crowd: the visibility-enhancing effects of IPO-related signals on alliance formation by entrepreneurial firms. Strategic Organization 5(4), 339-372.

Ponds, R., Van Oort, F., Frenken, K., 2007. The geographical and institutional proximity of research collaboration. Papers in Regional Science 86(3), 423-443.

Porter, M.E., 1996. Competitive advantage, agglomeration economies, and regional policy. International Regional Science Review 19(1-2), 85-90.

Rasmussen, E., Mosey, S., Wright, M., 2011. The evolution of entrepreneurial competencies: A longitudinal study of university spin-off venture emergence. Journal of Management Studies 48(6), 1314-1345.

Rodríguez-Gulías, M.J., Rodeiro-Pazos, D., Fernández-López, S. 2017. The growth of university spin-offs: a dynamic panel data approach, Technology Analysis \& Strategic Management 29(10), 1181-1195.

Rothaermel, F.T., Thursby, M., 2005. University-incubator firm knowledge flows: assessing their impact on incubator firm performance. Research Policy, 34(3), 305-320.

Sapienza, H.J., Autio, E., George, G., Zahra, S.A., 2006. A capabilities perspective on the effects of early internationalization on firm survival and growth. Academy of Management Review 31(4), 914-933.

Schumacker, R.E., Lomax, R.G., 2004. A beginner's guide to structural equation modeling. Psychology Press.

Schwartz, M., 2011. Incubating an illusion? Long-Term incubator firm performance after graduation. Growth and Change 42(4), 491-516.

Schwartz, M., Hornych, C., 2010. Cooperation patterns of incubator firms and the impact of incubator specialization: Empirical evidence from Germany. Technovation 30(9), 485-495.

Sears, J., Hoetker, G., 2014. Technological overlap, technological capabilities, and resource recombination in technological acquisitions. Strategic Management Journal 35(1), 4867.

Shepherd, D.A., McMullen, J.S., Ocasio, W., 2016. Is that an opportunity? An attention model of top managers' opportunity beliefs for strategic action. Strategic Management Journal 38(3), 626-644.

Slater, S.F., Mohr, J.J., Sengupta, S., 2014. Radical product innovation capability: Literature review, synthesis, and illustrative research propositions. Journal of Product Innovation Management 31(3), 552-566.

Soetanto, D., Jack, S., 2016. The impact of university-based incubation support on the innovation strategy of academic spin-offs. Technovation 50, 25-40.

Steffensen, M., Rogers, E. M., Speakman, K., 2000. Spin-offs from research centers at a research university. Journal of Business Venturing, 15(1), 93-111.

Stinchcombe, A.L., March, J.G., 1965. Social structure and organizations. Handbook of Organizations, 142-193.

Stuart, T.E., Sorenson, O., 2007. Strategic networks and entrepreneurial ventures. Strategic Entrepreneurship Journal 1(3-4), 211-227. 
Sydow, J., Schreyögg, G., Koch, J., 2009. Organizational path dependence: Opening the black box. Academy of Management Review 34(4), 689-709.

Svensson, P., Klofsten, M., Etzkowitz, H. (2012). An entrepreneurial university strategy for renewing a declining industrial city: The Norrköping way. European Planning Studies, 20(4), 505-525.

Taheri, M., van Geenhuizen, M., 2011. How human capital and social networks may influence the patterns of international learning among academic spin-off firms. Papers in Regional Science 90(2), 287-311.

Taheri, M., van Geenhuizen, M., 2016. Teams' boundary-spanning capacity at university: Performance of technology projects in commercialization. Technological Forecasting and Social Change 111, 31-43.

Tavoletti, E., 2013. Business incubators: effective infrastructures or waste of public money? Looking for a theoretical framework, guidelines and criteria. Journal of the Knowledge Economy 4, 423-443.

Teece, D.J., 2009. Dynamic capabilities and strategic management: Organizing for innovation and growth. Oxford University Press.

Todnem By, R., 2005. Organisational change management: A critical review. Journal of Change Management 5(4), 369-380.

Treibich, T., Konrad, K., Truffer, B., 2013. A dynamic view on interactions between academic spin-offs and their parent organizations. Technovation 33(12), 450-462.

Van Geenhuizen, M., Soetanto, D.P., 2013. Benefitting from learning networks in "open innovation": Spin-off firms in contrasting city regions. European Planning Studies 21(5), 666-682.

Van Geenhuizen, M., Ye, Q., Taheri, M. (2016). Hidden mediator roles of university spin-offs in Triple Helix networks. Triple Helix 3, 1-16.

Van Weele, M., van Rijnsoever, F.J., Nauta, F., 2017.You can't always get what you want: How entrepreneurs' perceived needs affect the incubator's assertiveness. Technovation 59, 18-33.

Vohora, A., Wright, M., Lockett, A., 2004. Critical junctures in the development of university high-tech spinout companies. Research Policy 33(1), 147-175.

Walter, A., Auer, M., Ritter, T., 2006. The impact of network capabilities and entrepreneurial orientation on university spin-off performance. Journal of Business Venturing 21(4), 541-567.

Zahra, S.A., 1991. Predictors and financial outcomes of corporate entrepreneurship: An exploratory study. Journal of Business Venturing 6(4), 259-285.

Zahra, S.A., 1993. Environment, corporate entrepreneurship, and financial performance: A taxonomic approach. Journal of Business Venturing, 8(4), 319-340.

\section{Appendix}

To illustrate the findings, the non-linear relationship between proximity and performance where entrepreneurial orientation plays a moderating role are presented in figure 1. As Aiken et al. (1991) suggest, we estimated simple slopes at three levels of proximity: low (one standard deviation below the maximum of the regression), intermediate (maximum of the regression curve) and high (one standard deviation above the maximum of the curve). 
Figure 1 here

Table 6 presents several case studies that illustrate the relationship between university and spin-offs. The following list shows the types of activities/interaction during and after incubation, from the perspective of the spin-off firms:

1) Receive seed capital

2) Access to accommodation and courses, and laboratory facilities for a limited period

3) Participate in management training to increase founding team capacity

4) Receive advice

5) Participate in collaborative research/projects

6) Join supervision (MSc and $\mathrm{PhD}$ )

7) Join research in cutting edge technology with university researchers

8) Provide employment opportunity for students

9) Gain credibility towards investors

Table 6 here 
Table 1

Descriptive statistics and correlation table

\begin{tabular}{|c|c|c|c|c|c|c|c|c|c|c|}
\hline & $\mathbf{M}$ & SD & 1 & 2 & 3 & 4 & 5 & 6 & 7 & 8 \\
\hline Control factors & & & & & & & & & & \\
\hline $\begin{array}{l}\text { 1. Size of founding } \\
\text { team }\end{array}$ & 2.30 & 1.20 & & & & & & & & \\
\hline 2. Age of spin-offs & 6.50 & 1.60 & .13 & & & & & & & \\
\hline $\begin{array}{l}\text { 3. Level of } \\
\text { innovativeness }\end{array}$ & .23 & .50 & .13 & -.09 & & & & & & \\
\hline 4. Spatial proximity & 36.00 & 16.00 & -.11 & .09 & .07 & & & & & \\
\hline 5. Social proximity & .46 & .24 & $.25 *$ & .15 & .08 & $.22 \dagger$ & & & & \\
\hline $\begin{array}{l}\text { 6.Research-oriented } \\
\text { spin-offs }\end{array}$ & $\begin{array}{l}0: 55 \% \\
1: 45 \%\end{array}$ & .78 & $-.05 * *$ & .10 & $.32 * *$ & .12 & $.24 *$ & & & \\
\hline $\begin{array}{l}\text { 7.Entrepreneurial } \\
\text { orientation (EO) }\end{array}$ & 4.40 & 1.40 & 27 & .13 & $.19 \dagger$ & -.17 & .02 & -.06 & & \\
\hline 8. Market hostility & 4.50 & 1.20 & $.17 \dagger$ & -.15 & $.25 *$ & $-.37 * *$ & .14 & -.13 & -.02 & \\
\hline 9. Performance & 3.89 & 1.10 & -.05 & .24 & .07 & $.42 * *$ & $.49 * *$ & .32 & -.17 & -.16 \\
\hline
\end{tabular}

$\dagger \mathrm{p}<.10 ;{ }^{*} \mathrm{p}<0.05 ; * * \mathrm{p}<.01$

Table 2

Regression results with spatial and social proximity as dependent variables

\begin{tabular}{|c|c|c|}
\hline & Spatial proximity & Social proximity \\
\hline \multicolumn{3}{|l|}{ Control factors } \\
\hline Size of founding team & $-0.29(1.40)$ & $0.05(0.02) * *$ \\
\hline Age of spin-offs & $0.69(0.99)$ & $0.02(0.01)$ \\
\hline Innovativeness & $2.30(3.10)$ & $0.03(0.05)$ \\
\hline \multicolumn{3}{|l|}{ Model variables } \\
\hline Research-oriented spin-offs & $3.90(2.10)^{*}$ & $1.21(1.03) *$ \\
\hline Entrepreneurial orientation & $0.65(1.10)$ & $0.04(0.02) * *$ \\
\hline Market hostility & $4.80(1.30)^{* *}$ & $0.03(0.02)$ \\
\hline $\mathrm{R}^{2}$ & .19 & 0.17 \\
\hline Adjusted $\mathrm{R}^{2}$ & .14 & 0.11 \\
\hline F statistics & $3.60 * *$ & $3.10 * *$ \\
\hline
\end{tabular}

Note: the spatial proximity scale was inverted, therefore, the higher the scale the closer the proximity between the spin-off and the university. $\dagger p<0.10 ; * * p<0.05 ; * * * p<0.01$

Table 3

Regression results testing the curvilinear relationship

\begin{tabular}{|l|c|c|c|c|}
\hline & Model 1 & Model 2 & Model 3 & Model 4 \\
\hline Control factors & & & & \\
\hline Size of founding team & $-0.01(0.09)$ & $-0.11(0.08)$ & $-0.02(0.09)$ & $-0.10(0.07)$ \\
\hline Age of spin-offs & $0.13(0.06)^{* *}$ & $0.09(0.06)^{*}$ & $0.14(0.06)^{* *}$ & $0.06(0.05)$ \\
\hline Level of innovativeness & $0.10(0.19)$ & $0.09(0.18)$ & $0.16(0.19)$ & $0.13(0.17)$ \\
\hline Research-oriented spin-offs & $-0.14(0.13)$ & $-0.21(0.07)^{*}$ & $-0.0(0.13)$ & $-0.16(0.11)$ \\
\hline Entrepreneurial orientation & $.20(0.07)^{* *}$ & $0.12(0.06)^{*}$ & $0.15(0.07)^{* *}$ & $0.14(0.06)^{* *}$ \\
\hline Market hostility & $0.03(0.09)$ & $-0.15(0.08)$ & $0.05(0.08)$ & $-0.18(0.07)^{* *}$ \\
\hline Spatial proximity & $0.02(0.01)^{* *}$ & & $0.08(0.03)^{* *}$ & \\
\hline Social proximity & & $2.10(0.40)^{* *}$ & & $7.30(1.30)^{* *}$ \\
\hline Spatial proximity & & & $-.01(0.01)^{* *}$ & \\
\hline Social proximity & & & $-5.60(1.30)^{* *}$ \\
\hline $\mathrm{R}^{2}$ & & & 0.34 & 0.48 \\
\hline Adjusted R & & 0.38 & 0.28 & 0.44 \\
\hline F statistics & 0.29 & $8.10^{* *}$ & $5.90^{* *}$ & $11.00^{* *}$ \\
\hline
\end{tabular}

Note: $\dagger p<0.10 ; * * p<0.05 ; * * * p<0.01$ 
Table 4

Regression results testing the moderation and curvilinear relationship

\begin{tabular}{|c|c|c|c|c|}
\hline & $\begin{array}{c}\text { Coefficient of } \\
\text { variable }\end{array}$ & $\mathbf{R 2}$ & Adjusted R2 & F statistics \\
\hline \multicolumn{5}{|l|}{ Spatial proximity } \\
\hline $\begin{array}{l}\text { Spatial proximity x Entrepreneurial } \\
\text { orientation }\end{array}$ & $-0.26(0.21)^{* *}$ & 0.49 & 0.44 & $9.70 * *$ \\
\hline $\begin{array}{l}\text { Spatial proximity }{ }^{2} \text { x Entrepreneurial } \\
\text { orientation }\end{array}$ & $-.21(0.41)^{* *}$ & 0.47 & 0.42 & $9.00 * *$ \\
\hline $\begin{array}{l}\text { Spatial proximity x Research-oriented } \\
\text { spin-offs }\end{array}$ & $0.03(0.09)$ & 0.34 & 0.27 & $5.20 * *$ \\
\hline $\begin{array}{l}\text { Spatial proximity }{ }^{2} \text { x Research-oriented } \\
\text { spin-offs }\end{array}$ & $-.01(0.01)$ & 0.34 & 0.27 & $5.2 * *$ \\
\hline Spatial proximity x Market hostility & $0.07(0.06)$ & 0.35 & 0.29 & $5.40 * *$ \\
\hline Spatial proximity ${ }^{2} \mathrm{x}$ Market hostility & $0.01(0.01)$ & 0.34 & 0.28 & $5.20 * *$ \\
\hline \multicolumn{5}{|l|}{ Social proximity } \\
\hline $\begin{array}{l}\text { Social proximity x Entrepreneurial } \\
\text { orientation }\end{array}$ & $-0.80(0.25)^{* *}$ & 0.54 & 0.49 & $12.00 * *$ \\
\hline $\begin{array}{l}\text { Social proximity }{ }^{2} \text { x Entrepreneurial } \\
\text { orientation }\end{array}$ & $-0.87(0.28)^{* *}$ & 0.54 & 0.49 & $12.00 * *$ \\
\hline $\begin{array}{l}\text { Social proximity x Research-oriented } \\
\text { spin-offs }\end{array}$ & $0.39(0.44)$ & 0.49 & 0.44 & $9.6 * *$ \\
\hline $\begin{array}{l}\text { Social proximity }{ }^{2} \times \text { Research-oriented } \\
\text { spin-offs }\end{array}$ & $0.36(0.45)$ & 0.49 & 0.44 & $9.60 * *$ \\
\hline Social proximity x Market hostility & $0.53(0.31)^{*}$ & 0.50 & 0.45 & $10.00 * *$ \\
\hline Social proximity ${ }^{2} \mathrm{x}$ Market hostility & $0.47(0.31)$ & 0.50 & 0.45 & $9.90 * *$ \\
\hline
\end{tabular}

Note: $\uparrow p<0.10 ; * * p<0.05 ; * * * p<0.01$

Table 5

Hypothesis testing

\begin{tabular}{|l|l|}
\hline \multicolumn{1}{|c|}{ Hypotheses } & \multicolumn{1}{|c|}{ Results } \\
\hline $\begin{array}{l}\text { H1. Academic spin-offs with research-oriented founders are more likely to } \\
\text { maintain physical and social proximity to the university after graduating } \\
\text { from the incubator. }\end{array}$ & $\begin{array}{l}\text { Confirmed for spatial and } \\
\text { social proximity }\end{array}$ \\
\hline $\begin{array}{l}\text { H2. Academic spin-offs with high entrepreneurial orientation are more likely } \\
\text { to maintain social and spatial proximity to universities after graduating from } \\
\text { incubators. }\end{array}$ & $\begin{array}{l}\text { Confirmed for social } \\
\text { proximity only }\end{array}$ \\
\hline $\begin{array}{l}\text { H3. Academic spin-offs facing hostile markets are more likely to maintain } \\
\text { spatial and social proximity to universities after graduating from incubators. }\end{array}$ & $\begin{array}{l}\text { Confirmed for spatial } \\
\text { proximity only }\end{array}$ \\
\hline $\begin{array}{l}\text { H4. Spatial and social proximity have an inverted U-shaped relationship } \\
\text { with spin-off performance. }\end{array}$ & $\begin{array}{l}\text { Confirmed for spatial and } \\
\text { social proximity }\end{array}$ \\
\hline $\begin{array}{l}\text { H5. Research-oriented spin-offs moderate the inverted U-shaped relation } \\
\text { between proximity and performance such that research-oriented spin-offs } \\
\text { experience stronger performance as a result of balancing proximity to the } \\
\text { university compared to spin-offs that focus less on research. }\end{array}$ & Rejected \\
\hline $\begin{array}{l}\text { H6. Entrepreneurial orientation moderates the inverted U-shaped relation } \\
\text { between proximity and performance such that spin-offs with high } \\
\text { entrepreneurial orientation will exhibit stronger performance as a result of } \\
\text { balancing proximity to the university compared to spin-offs with low } \\
\text { entrepreneurial orientation. }\end{array}$ & $\begin{array}{l}\text { Confirmed for spatial and } \\
\text { social proximity }\end{array}$ \\
\hline $\begin{array}{l}\text { H7. Market hostility moderates the inverted U-shaped relation between } \\
\text { proximity and performance such that spin-offs with high market hostility will }\end{array}$ & Rejected \\
\hline
\end{tabular}


exhibit stronger performance as a result of balancing proximity to the university compared to spin-offs with low market hostility.

Table 6 Parent university support/interaction (marked * if at founding or during incubation) and recent events in spin-off growth

Case study 1: research-oriented spin-off

Invention: Device for multiple electron beam lithography

Market: Global with a few players

Market hostility: High (disruptive solution, not yet accepted in market)

Established: 2000 by university professor (physics)

Parent university support/interaction: multi-faceted

Proximity-related

- Founding by university professor*

- Nurtured in faculty room and laboratories*

- University as a modest shareholder*

- Sharing Master and PhD students research

- Participation in joint research programs

\section{Social network-related}

- $\quad$ Later on, managed by three graduates from physics department at university

- $\quad$ Founding professor in advisory role

- (Indirect) credibility towards investors

\section{Recent events in growth:}

- 2009: start collaboration with research institute in France (incl. investment) and Taiwan (prototype testing)

- $\quad$ +/-2010: relocation to premises adjacent to campus

- 2012: major investment by NL-Russia consortium and start of subsidiary in Moscow

- 2015: (official) introduction of invention to market

- connected: search for partner for larger scale manufacturing and financial investment

- 2016: attention to new application in development of e-beam security ICs (joint venture in NL)

Employment size (1-1-2017): 270

Comments: Since its start, this spin-off has only sold two prototypes for testing in 2009 aside from some knowledge in other forms. It may be that a certain inertia has developed.

Sources: two interviews (2007 and 2012) by one of the authors; use of newspaper and branch journal coverage, website communication in 2016.

\section{Case study 2: Research-oriented spin-off}

Invention: New materials (high quality ceramic powder) to be used in batteries, fuel cells etc.

Market: Global with limited number of players

Market hostility: Not applicable; growing markets

Established: 2007 by three university professors (material science)

Parent university support/interaction: multi-faceted

Proximity-related

- Established as joint venture of three university professors and Technology Transfer Centre (access to investment capital)*

- $\quad$ Nurtured in faculty room, using equipment of university*

- Sharing Master and PhD students research

- Participation in joint research programs (EU)

- Testing of materials and co-production with various research groups at university

Social network-related

- $\quad$ Later on, founding professors act as advisors

- (Indirect) Credibility towards investors

Main recent events/developments:

- $\quad$ Since 2009: served selected research groups at universities

- Since 2013: broadened focus with industrial customers (outside university)

- 2013: relocated to nearby site - pilot factory (maintain close collaboration)

Employment size (1-1-2017): approx. 10 
Comments: Seems stable, without strong growth.

Sources: Interview in 2014 by $\mathrm{PhD}$ student; use of newspaper and branch journal coverage, website communication in 2016.

Case study 3: Entrepreneurial-oriented spin-off

Invention: Sun simulator for testing of quality/condition of solar cells (highest accuracy)

Market: Global with limited number of players

Market hostility: Not applicable; growing markets

Established: 2011 by master students (of which one business school education)

\section{Parent university support/interaction: single-facet}

Proximity-related

- Nurtured in university incubator and use of university facilities*

Social network-related

- Co-development of invention in consortium (partly in region)*

- Sponsorship of parent university's 'student challenge' (solar team/boat)

- (Indirect) Credibility towards subsidy providers and investor

Main recent events/developments:

- 2012: Development of prototype (and certification); focus on market of research organizations/universities

- 2014 Relocation to premises at close distance of parent university

- 2013/14 Additional focus on providing testing services (risk-avoiding and learning with customers)

- 2014: Acquisition of US firm and additional focus on market segment of solar cell manufacturers

Employment size (1-1-2017): ca. 25

Comments: Moderate growth with limited support/interaction of parent university, stronger in interaction in larger consortia

Sources: Interview 2012 by one of the authors; use of newspaper and branch journal coverage, website communication in 2016.

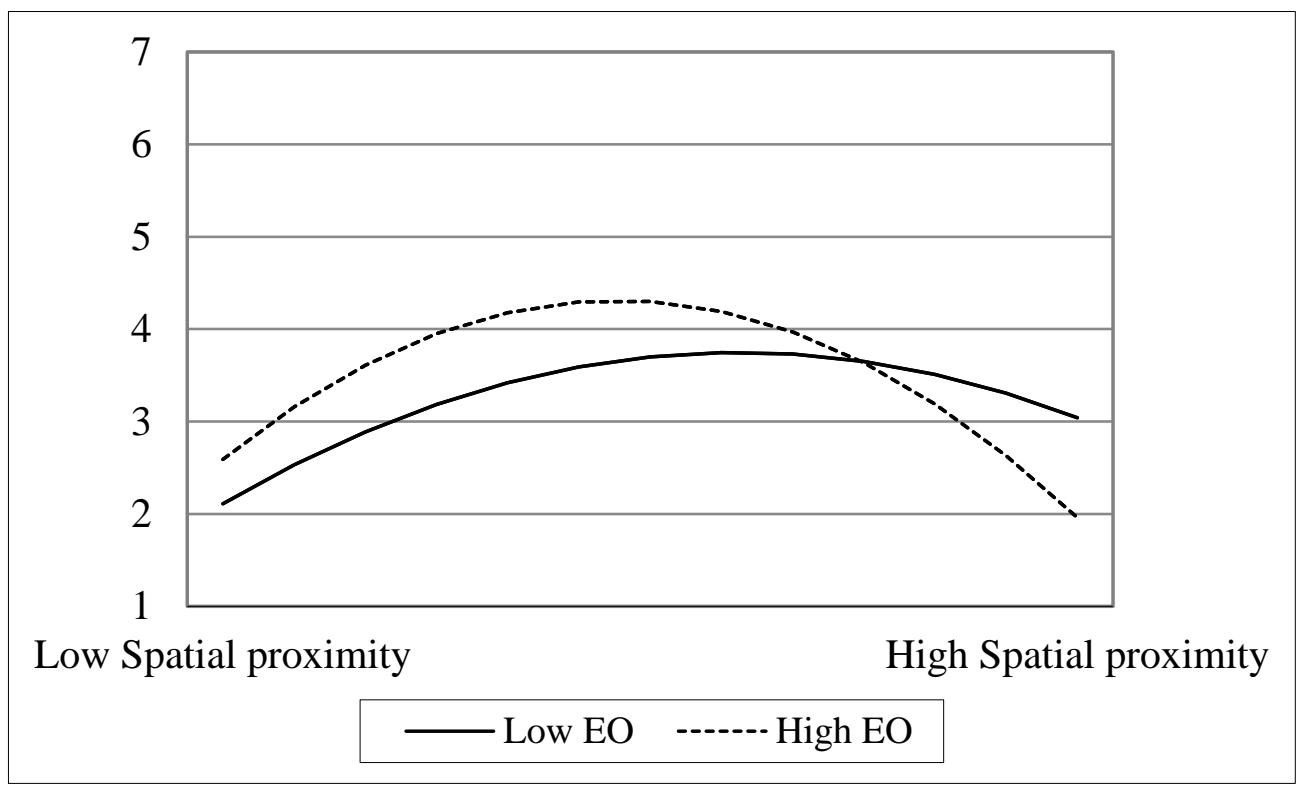




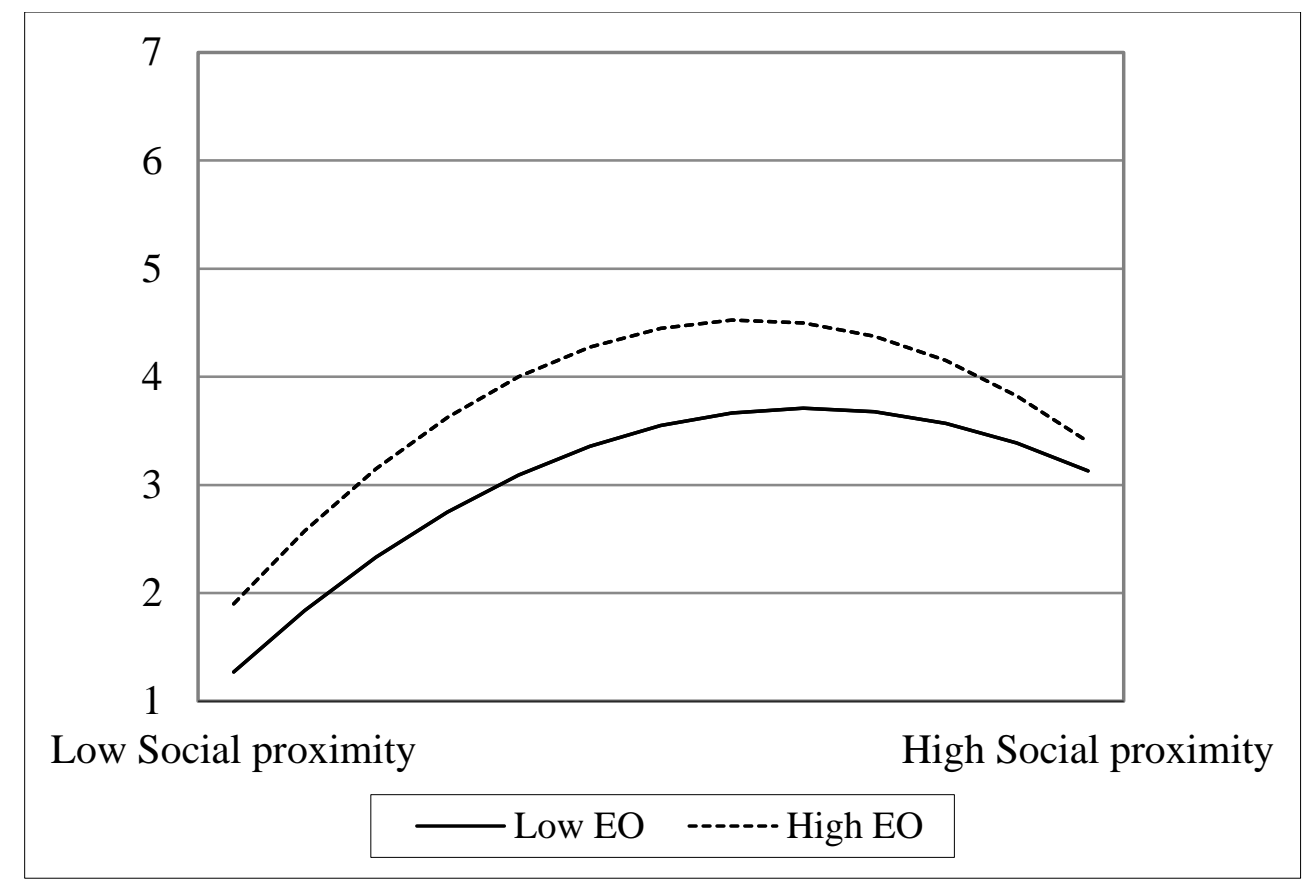

Fig 1. Illustration of the curvilinear relationship and the moderation role of entrepreneurial orientation. 